\title{
The Neighborhoods of New York City
}

K E N N E T H T . J A C K S O N, G E N E R A L E I I T O R

\section{A ID V I S O R Y I O A R D}

\section{Osborn Elliott Founding}

Chairman, Citizens Committee

for New York City

Henry Cornell Chairman,

Citizens Committee

for New York City

Peter H. Kostmayer President,

Citizens Committee

for New York City

\section{Thomas H. Guinzburg}

Director Emeritus,

Citizens Committee

for New York City
Although outsiders often regard New York City as an undifferentiated mass of 8 million rude, indifferent people, Gotham is in fact a collection of more than 400 individual neighborhoods, each containing its fill of involved and friendly residents and each cherishing a unique sense of identity and place. Here, as elsewhere in America, locally owned haberdasheries, hardware stores, delicatessens, greengroceries, and bakeries along main streets compete with shopping centers and malls, but it is still a fact that New York is almost the last place in the nation where neighbors routinely pass one another on the sidewalk or exchange greetings at a corner store, in the local park, or at a community center. From stoops and front porches they discuss news of their block, or of the world. Indeed, New York has become the best place in the United States to experience what was once the essence of small-town America. 


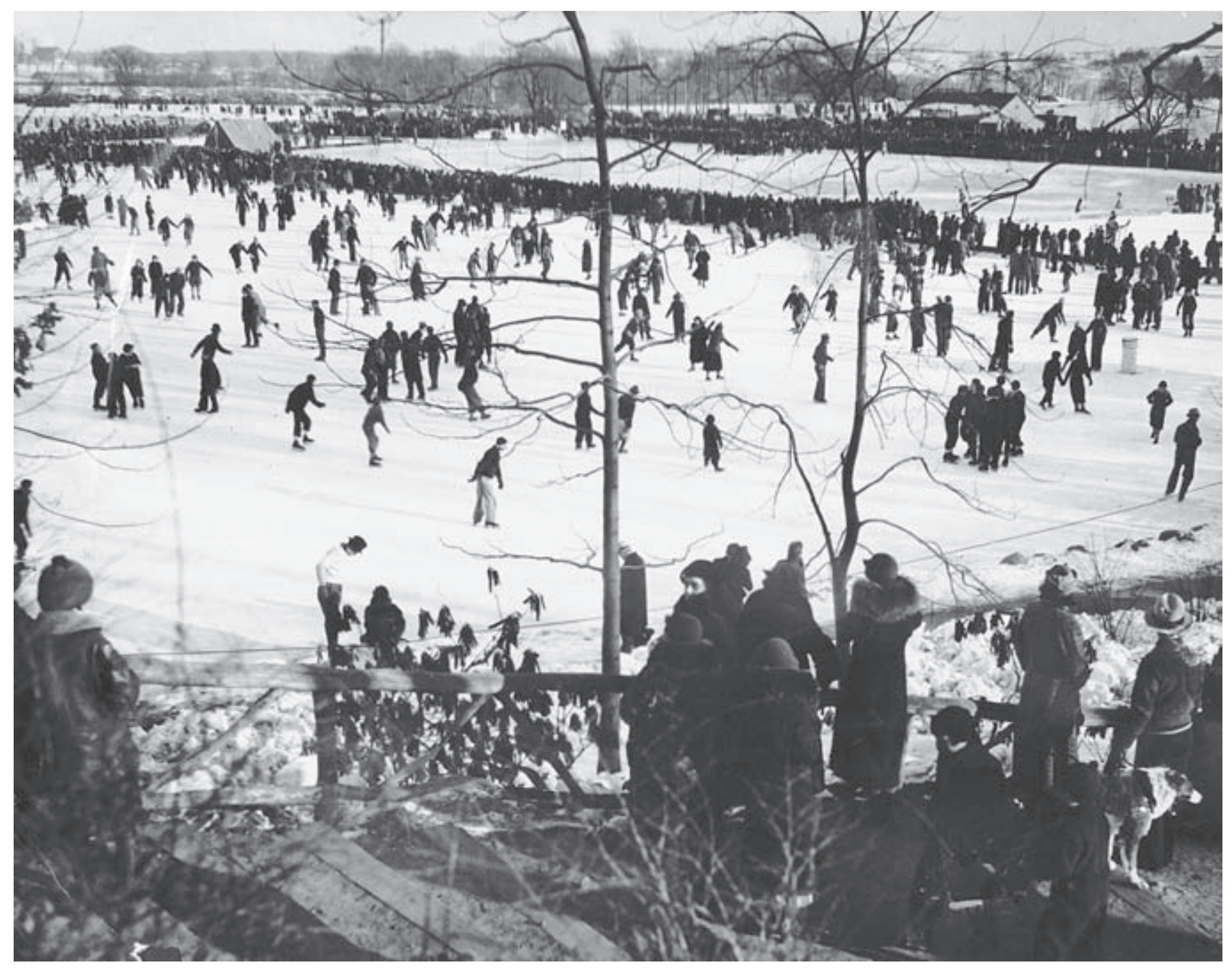




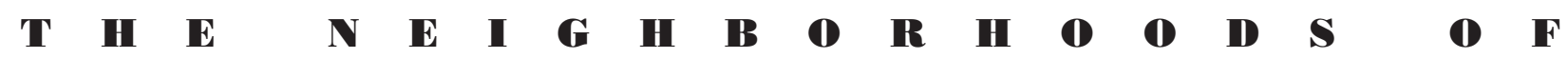

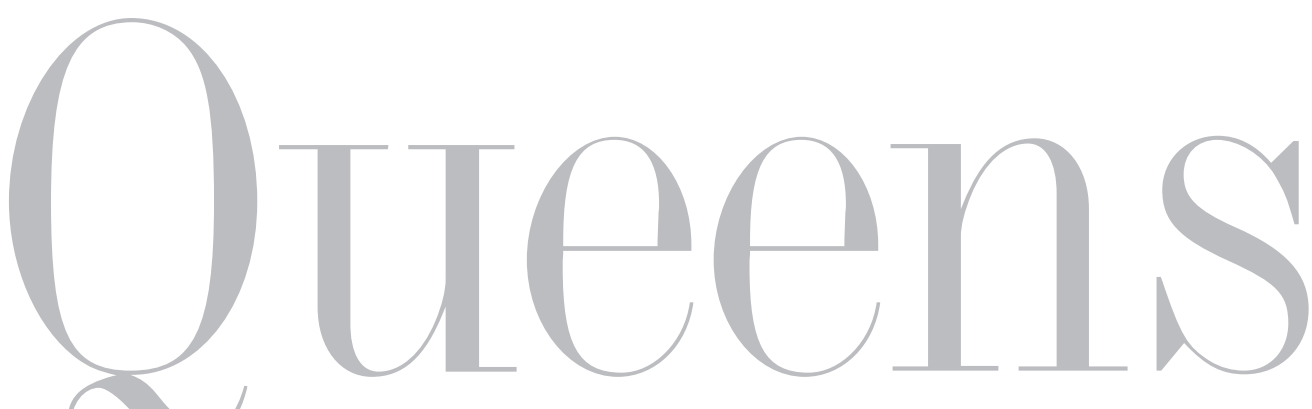

Claudia Gryvatz Copquin

Introduction by Kenneth T. Jackson

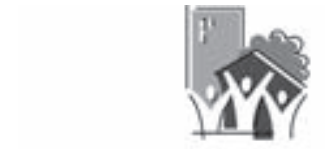

CITIZENS COMMITTEE

FOR NEW YORK CITY

Yale University Press — New Haven and London 


\section{P R O J E C T S T A F F}

Sonia S. Estreich,

Managing Editor

Michelle LeMay-Santiago,

Development

Jemilah Magnusson,

Project Coordinator

Mary Jane Peluso, Publisher

Lauren Shapiro,

Sponsoring Editor

Vadim Staklo, Sponsoring Editor

Julie Carlson,

Development Editor

Susan Laity, Manuscript Editor

Steve Colca, Assistant Editor

Laura Robb, Editorial Assistant

Ray Anastas, Photographer

William L. Nelson, Cartographer

Colette Nelson, Cartographer

Timothy Calabrese, Demographer

Kaleila Pu-Folkes, Mapping and Pro-

files Coordinator

Ana C. Diaz, Survey Coordinator

Christina Coffin,

Production Director

Karen Stickler,

Production Controller
Copyright $\left({ }_{2007}\right.$ by Citizens Committee for New York City. All rights reserved. This book may not be reproduced, in whole or in part, including illustrations, in any form (beyond that copying permitted by Sections 107 and 108 of the U.S. Copyright Law and except by reviewers for the public press), without written permission from the publishers.

Photographs by Ray Anastas unless otherwise identified.

Photographs, p. ii: see p. 34; p. vi: Adam Coglianese, NYRA track photographer

Set in Bodoni type by Technologies 'N Typography, Inc. Printed in the United States of America.

Library of Congress Cataloging-in-Publication Data

Copquin, Claudia Gryvatz, $1961-$

The neighborhoods of Queens / Claudia Gryvatz Copquin ; introduction by Kenneth T. Jackson. p. cm.- (The neighborhoods of New York City) Includes bibliographical references and index. ISBN 978-o-30o-11299-3 (alk. paper)
1. Queens (New York, N.Y.)—Description and travel. 2. New York (N.Y.)—Description and

travel. 3. Neighborhood-New York (State)—New York. 4. Queens (New York, N.Y.)-History. 5. New York (N.Y.)—History. 6. Queens (New York, N.Y.)—Biography. 7. New York (N.Y.)— Biography. 8. Historic buildings-New York (State)—New York. 9. Queens (New York,

N.Y.)—Buildings, structures, etc. 10. New York

(N.Y.)-Buildings, structures, etc. I. Title. $\mathrm{F}_{128.68 . Q_{4} \mathrm{C}_{7} 2007}$

$917.47^{\prime} 243-\mathrm{dc} 22 \quad 2007013716$

A catalogue record for this book is available from the British Library.

The paper in this book meets the guidelines for permanence and durability of the Committee on Production Guidelines for Book Longevity of the Council on Library Resources.

$\begin{array}{llllllllll}10 & 9 & 8 & 7 & 6 & 5 & 4 & 3 & 2 & 1\end{array}$ 
Major support for The Neighborhoods of Queens was provided by JPMorgan Chase

Additional support was provided by

- Furthermore, a program of the J.M. Kaplan Fund

- Ben-Ness Photos \& Digital 


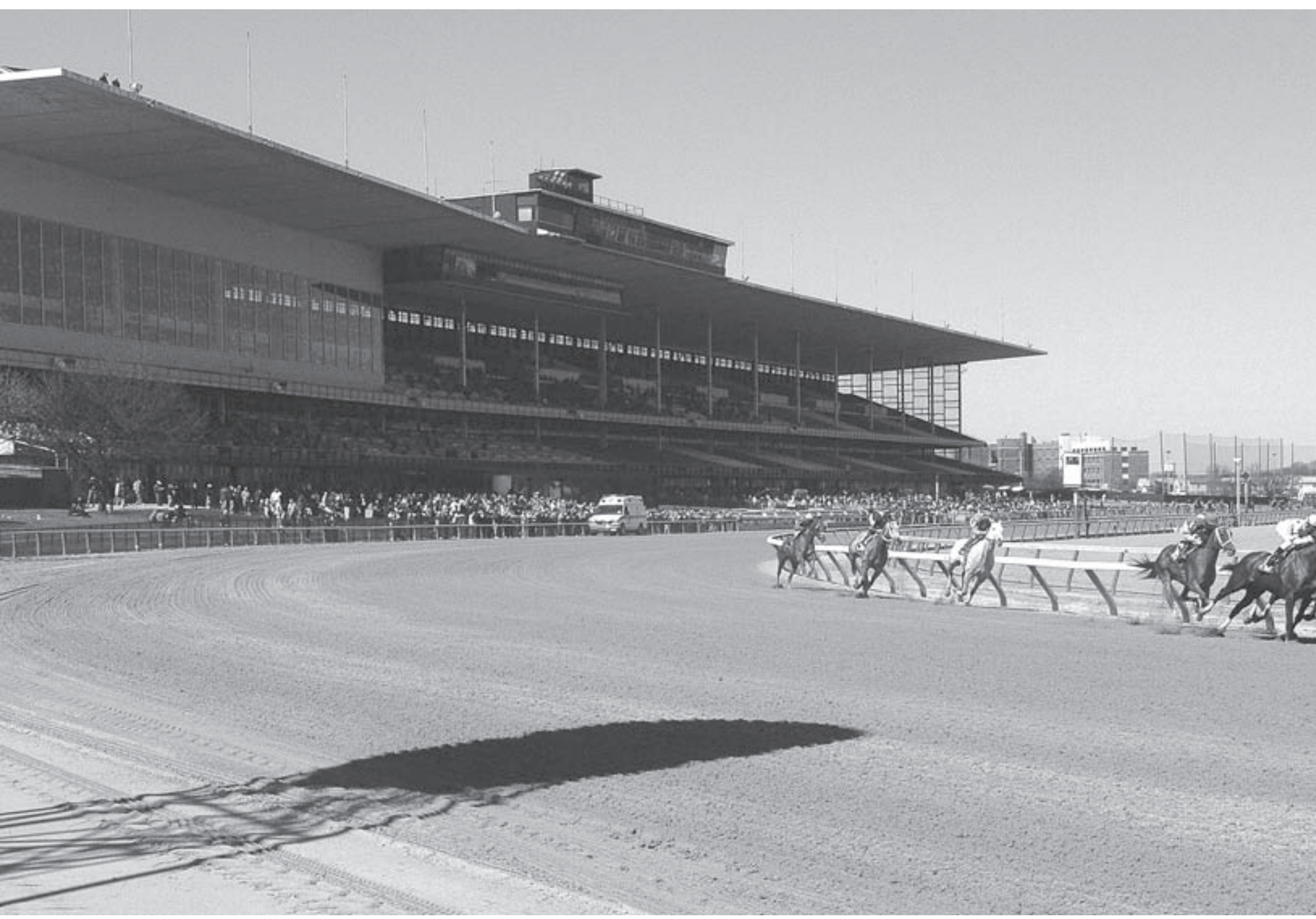

